\title{
Corrosion Behaviour of TiC-Reinforced Hadfield Manganese Austenitic Steel Matrix In-Situ Composites
}

\author{
Ashok Kumar Srivastava ${ }^{*}$, Karabi Das ${ }^{2}$, Sandeep Kr. Toor ${ }^{3}$ \\ ${ }^{1}$ Centre of Excellence, Department of Metallurgical Engineering, School of Engineering, O. P. Jindal University, \\ Raigarh, India \\ ${ }^{2}$ Department of Metallurgical and Materials Engineering, Indian Institute of Technology, Kharagpur, India \\ ${ }^{3}$ Steel Foundry, Bokaro Steel Plant, Steel Authority of India Limited, Bokaro, India \\ Email: ${ }^{\text {ashok.iitkg@yahoo.co.uk }}$
}

Received 8 April 2015; accepted 27 June 2015; published 30 June 2015

Copyright (C) 2015 by authors and Scientific Research Publishing Inc.

This work is licensed under the Creative Commons Attribution International License (CC BY).

http://creativecommons.org/licenses/by/4.0/

c) (7) Open Access

\begin{abstract}
The corrosion behaviour of Hadfield manganese austenitic steel matrix composite reinforced with the varying amount of TiC and unreinforced Hadfield manganese austenitic steel matrix alloy has been evaluated in 3.5\% $\mathrm{NaCl}$ aqueous solution with the pH value of 6 by the potentiodynamic polarization curves and linear polarization resistance measurements at a scan rate of $1 \mathrm{mV} / \mathrm{s}$ at room temperature $\left(25^{\circ} \mathrm{C} \pm 2^{\circ} \mathrm{C}\right)$. The corrosion rate of the composites is higher than that of their unreinforced matrix alloy and it increases with the increasing volume fraction of TiC. The poor corrosion resistance of the composites can be attributed to the galvanic effects between the matrix and reinforcement.
\end{abstract}

Keywords

Steel Matrix in Situ Composites, Titanium-Carbide, Corrosion Resistance

\section{Introduction}

Metal-matrix composites (MMCs) have a number of advantages over conventional metals and alloys. Among the different types of MMCs, particulate reinforced MMCs are widely used because of its low production cost and ease of fabrication. The addition of ceramic particles into a metal matrix increases the strength, hardness and wear resistance properties while the ductility decreases considerably. Although there are some reports on the

${ }^{*}$ Corresponding author.

How to cite this paper: Srivastava, A.K., Das, K. and Toor, S.Kr. (2015) Corrosion Behaviour of TiC-Reinforced Hadfield Manganese Austenitic Steel Matrix In-Situ Composites. Open Journal of Metal, 5, 11-17.

http://dx.doi.org/10.4236/ojmetal.2015.52002 
physical-mechanical properties of the carbide reinforced iron or steel matrix composites [1]-[4], only limited information is available concerning the corrosion characteristics of the carbide reinforced iron or steel matrix composites [5]-[7]. The carbide particles in the metal matrix serve as active cathodes and tend to reduce corrosion resistance of the metal matrix. The aim of the present paper is to investigate the corrosion behavior of Hadfield manganese austenitic steel matrix composite reinforced with the varying amount of TiC and unreinforced Hadfield manganese austenitic steel matrix alloy.

\section{Experimental Procedure}

The synthesis of Hadfield manganese austenitic steel matrix composites was carried out by simple stoichiometric method aiming 5 and 10-vol\% TiC in 1.23\% C, $11.53 \% \mathrm{Mn}, 0.42 \% \mathrm{Si}, 0.36 \% \mathrm{Al}, 0.33 \% \mathrm{Cr}, 0.008 \% \mathrm{~S}$, 0.019\% $\mathrm{P}$ and balance Fe (all in wt\%) Hadfield manganese austenitic steel matrix. The synthesis of the composites was carried in a $25 \mathrm{~kg}$ high frequency induction furnace (Inductotherm, India) in air by covering it with a ceramic block to prevent the oxidation of the melt to a certain extent. At first the blend of steel scrap (0.049\% C, 0.43\% Mn, 0.028\% Si, 0.023\% P, 0.013\% S, 0.003\% Al, 0.035\% Cr and balance Fe, all in wt\%) and cast iron (4.5\% C, $0.043 \% \mathrm{Mn}, 1.05 \% \mathrm{Si}, 0.175 \% \mathrm{P}, 0.043 \% \mathrm{~S}$ and balance Fe, all in wt\%) was heated to $1575^{\circ} \mathrm{C}$ and maintained at that temperature for 15 minutes and then the temperature was raised to $1610^{\circ} \mathrm{C}$. The calculated amount of Fe-Ti (70\% purity) and electrolytic manganese (95\% purity) were added to the melt at this temperature. The Fe-Ti was added to iron alloy melt by plunging due to lower density of Fe-Ti with respect to iron alloy melt. The melt was stirred continuously at $1620^{\circ} \mathrm{C}$ temperature for $10 \mathrm{~min}$ and subsequently cast in a metallic mould.

Scanning electron microscopy (SEM) technique has been used to examine the microstructure of composites and unreinforced matrix alloy before and after exposure to 3.5\% $\mathrm{NaCl}$ environment. EDS technique has been used to determine the elemental composition of the corroded surfaces. A galvanostatic DC power supply (Autolab PGSTAT 30) which can generate current pulses up to 10A was used for electrochemical polarization studies. Experiments were conducted using the standard three electrode configuration, with a platinum foil as a counter electrode, saturated calomel electrode as reference electrode and the sample as a working electrode. The electrolyte solution had a $\mathrm{pH}$ of $\sim 6$. The surface of the examined specimens was about $1 \mathrm{~cm}^{2}$. Specimens were immersed in the test solution of $3.5 \% \mathrm{NaCl}$ aqueous solution. Experiments were carried out at room temperature $\left(28^{\circ} \mathrm{C}\right)$. In order to establish the open circuit potential (OCP) before measurements, the samples were immersed in the solution for 100 seconds. After obtaining a stable OCP, the measurements were carried out by polarizing the specimen from +0.5 to $-0.5 \mathrm{~V}$ with respect to corrosion potential $\left(E_{\text {corr }}\right)$ at a scan rate of $1 \mathrm{mV}$ per sec and at a step potential of $0.45 \mathrm{mV}$ to construct the Tafel plots.

In corrosion test, quantitative information on corrosion currents and corrosion potentials can be extracted from the intersection of the slopes of the potentiodynamic linear polarization curves [8], using the Stern-Geary equation (1), as follows [9]:

$$
I_{\text {corr }}=\frac{1}{2.303 R_{p}}\left(\frac{b_{a} \times b_{c}}{b_{a}+b_{c}}\right)
$$

where, $I_{\text {corr }}$ is the corrosion current density in amps $/ \mathrm{cm}^{2}, R_{\mathrm{p}}$ is the polarization resistance in ohms $/ \mathrm{cm}^{2}, b_{a}$ is the anodic Tafel slope in volts/decade of current density and $b_{c}$ is the cathodic Tafel slope in volts/decade of current density. The corrosion rate can be calculated by $1^{\text {st }}$-Stern method, using the relation: Corrosion rate $=\left(C \omega I_{\text {corr }}\right) / \rho$, where $C$ is conversion factor, $\omega$ is the equivalent weight $(\mathrm{g})$ and $\rho$ is the density of the material $\left(\mathrm{g} / \mathrm{cm}^{3}\right)$.

The values of $E_{\text {corr }}, I_{\text {corr }}$, corrosion rate and $R_{p}$, as obtained from the potentiodynamic polarization curves are summarized in Table 1.

\section{Results and Discussion}

Figure 1(a) and Figure 1(b) show the as-cast microstructure of Hadfield manganese austenitic steel at low and high magnification, respectively. It has been observed that the (Fe, $\mathrm{Mn})_{3} \mathrm{C}$ carbides are mainly precipitated along the austenite grain boundaries. Some scattered (Fe, $\mathrm{Mn})_{3} \mathrm{C}$ carbides can be seen within the austenite grains. The formation of $(\mathrm{Fe}, \mathrm{Mn})_{3} \mathrm{C}$ carbides along the austenite grain boundaries leads to the depletion of carbon and manganese in the matrix adjacent to the carbide network leading to the decomposition of austenite to an alternative lamellae of $\alpha$-ferrite and ( $\mathrm{Fe}, \mathrm{Mn})_{3} \mathrm{C}$ carbides. 
Table 1. The electrochemical parameters of TiC-reinforced Hadfield manganese austenitic steel matrix composites and unreinforced Hadfield manganese austenitic steel.

\begin{tabular}{|c|c|c|c|c|}
\hline Material & $E_{\text {corr }}(\mathrm{V})$ & $I_{\text {corr }} \times 10^{-6}\left(\mathrm{~A} / \mathrm{cm}^{2}\right)$ & $\begin{array}{c}\text { Corrosion rate } \times 10^{-2} \\
(\mathrm{~mm} / \text { year })\end{array}$ & $\begin{array}{l}R_{\mathrm{p}} \times 10^{3} \\
\left(\Omega / \mathrm{cm}^{2}\right)\end{array}$ \\
\hline Hadfield manganese austenitic steel & -0.661 & 2.04 & 2.065 & 2.292 \\
\hline 5 vol\% TiC-reinforced composite & -0.809 & 6.95 & 5.173 & 1.969 \\
\hline 10 vol\% TiC-reinforced composite & -0.844 & 8.07 & 7.843 & 1.787 \\
\hline
\end{tabular}

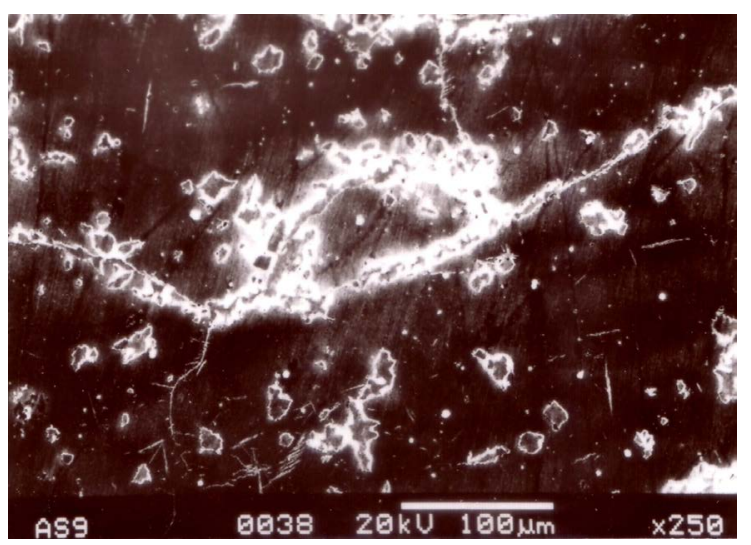

(a)

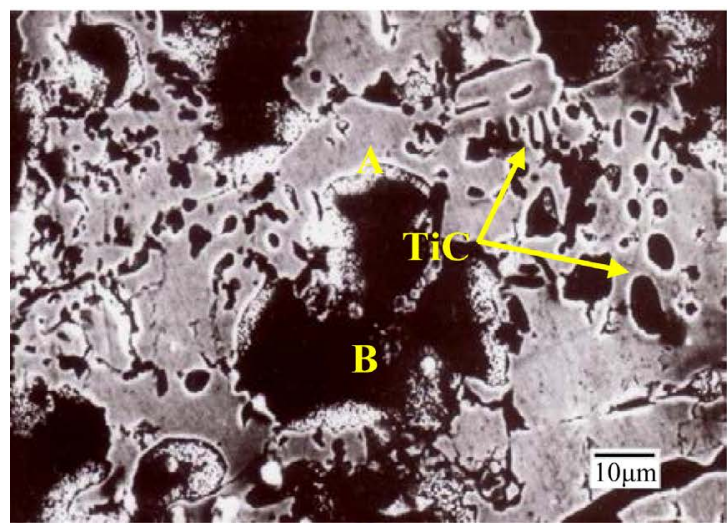

(c)

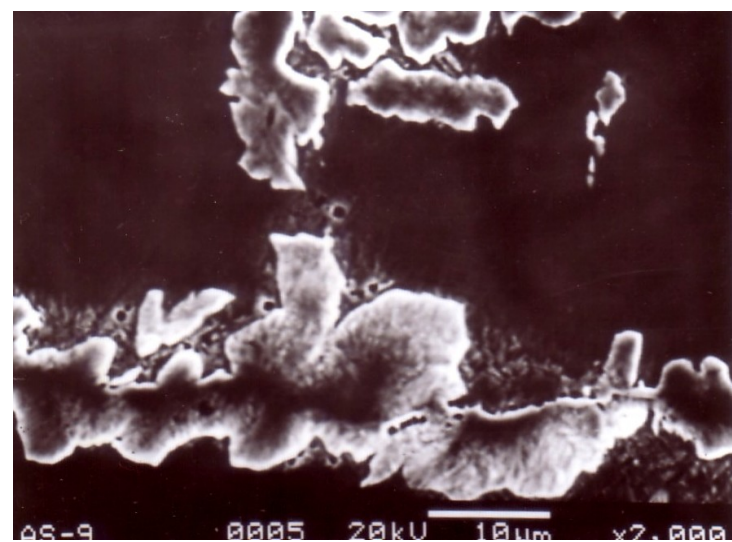

(b)

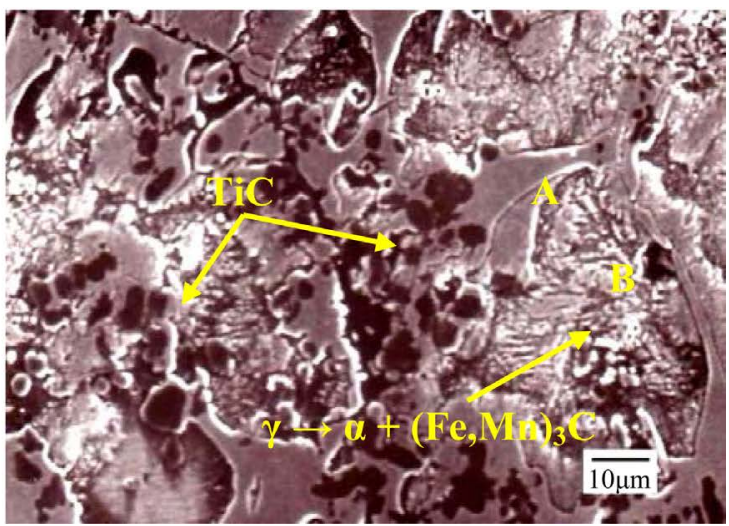

(d)

Figure 1. SEM micrographs of as-cast (a) and (b) Hadfield manganese austenitic steel, and (c) 5 and (d) 10 vol\% TiC-reinforced composites.

Figure 1(c) and Figure 1(d) show the as-cast SEM micrographs of 5 and 10 vol\% TiC-reinforced Hadfield manganese austenitic steel matrix composites, respectively. In these figures, 'A' represents the interdendritic area which is rich in manganese $(14 \%)$ and ' $\mathrm{B}$ ' represents the dendritic area which is depleted in manganese $(8 \%)$. The decomposition of the dendrites to $\alpha$-ferrite and (Fe, $\mathrm{Mn})_{3} \mathrm{C}$ is clearly revealed in the SEM micrograph of the composite with 10 vol\% TiC.

The XRD patterns, shown in Figures 2(a)-(c), confirm that the microstructure of Hadfield manganese austenitic steel consists of austenite, $\alpha$-ferrite and (Fe, Mn) ${ }_{3} \mathrm{C}$ carbides while the microstructures of the composites consist of austenite, $\alpha$-ferrite, (Fe, $\mathrm{Mn})_{3} \mathrm{C}$ and TiC.

It can be seen from Table 1 that the value of $R_{p}$ decreases with the increase in volume fraction of the reinforcement, and it is highest for Hadfield manganese austenitic steel among the all three tested materials. Therefore, Hadfield manganese austenitic steel exhibits better corrosion resistance than that of the composites and the composite with higher volume fraction of the reinforcement exhibits poor corrosion resistance. The potentiodynamic polarization curves obtained from potentiostat for the composites and Hadfield manganese austenitic steel are shown in Figure 3. All curves are similar, showing that the polarization behaviour of all the alloys, reinforced 

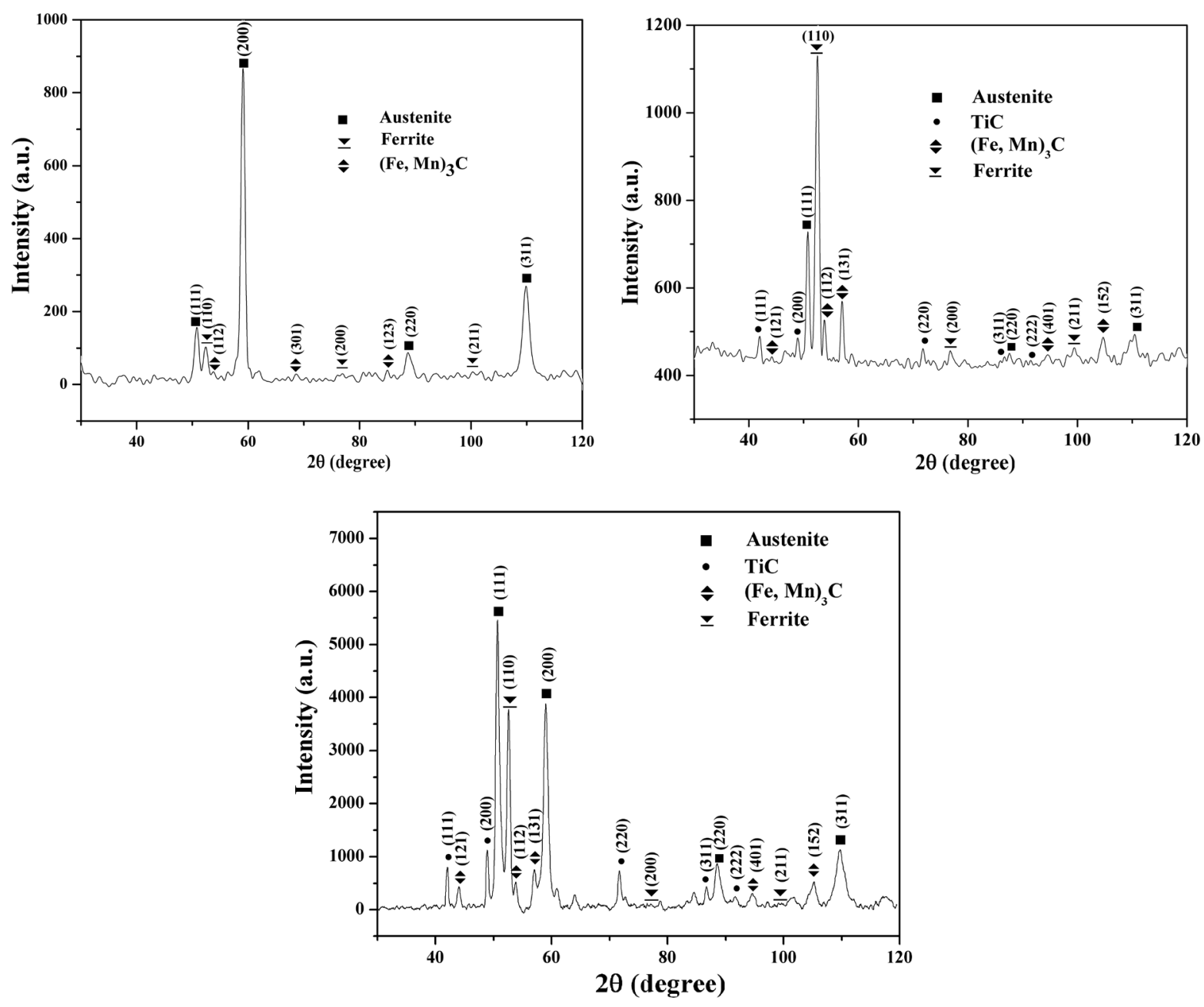

Figure 2. XRD of as-cast (a) Hadfield manganese austenitic steel, (b) 5 vol\% and (c) 10 vol\% TiC-reinforced composite.

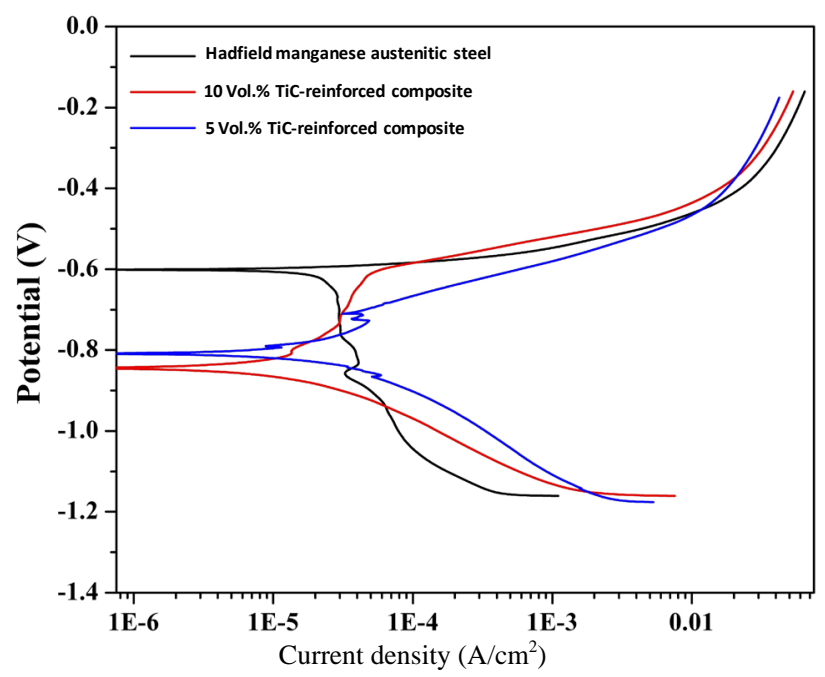

Figure 3. Corrosion behaviour of 5 and 10 vol\% TiC-reinforced composites and their unreinforced Hadfield manganese austenitic steel matrix alloy. 
and unreinforced, is in general quite similar. It has been observed that the $E_{\text {corr }}$ of the composites move to more negative direction and the values of $I_{\text {corr }}$ and corrosion rate increases as compared to that of the matrix alloy, which might be due to the galvanic coupling effect between the TiC particles and Hadfield manganese austenitic steel matrix.

The higher corrosion rates of composites compared to their matrix alloy can be attributed to the localized attack of the composites at the particle-matrix interface. The value of $E_{\text {corr }}$ of the composite with $10 \mathrm{vol} \% \mathrm{TiC}$ moves to more negative direction and the values of $I_{\text {corr }}$ and corrosion rate increase as compared to that of the composite with $5 \mathrm{vol} \% \mathrm{TiC}$. This behaviour can be attributed to the increased number of cathodic sites with the incorporation of higher amount of TiC particles in the matrix. The smaller anodic area due to an increase in cathodic sites sustains high current density resulting in higher corrosion rate. It has been observed from the corroded SEM micrograph (Figure 4(a)) of Hadfield manganese austenitic steel matrix alloy that the corrosion is of localized type. The localized galvanic corrosion takes place due to the formation of the local galvanic cells between austenite and ferrite or $(\mathrm{Fe}, \mathrm{Mn})_{3} \mathrm{C}$ in $3.5 \% \mathrm{NaCl}$ solution open to the air. The area of localized corrosion as pitting are coved with the corrosion products and having cracks on the surface. These cracks might form due to drying out of the corrosion products.

The EDX analysis (Figure 5) of the corrosion products has shown the presence of the oxides of iron and manganese. The EDX spectrum of corrosion products (Figure 5) shows the presence of Si and S. Sulfur, which forms $\mathrm{MnS}$ has a strong effect on the pitting corrosion resistance and due to which the Fe-Mn matrix is more sensitive to pitting corrosion.

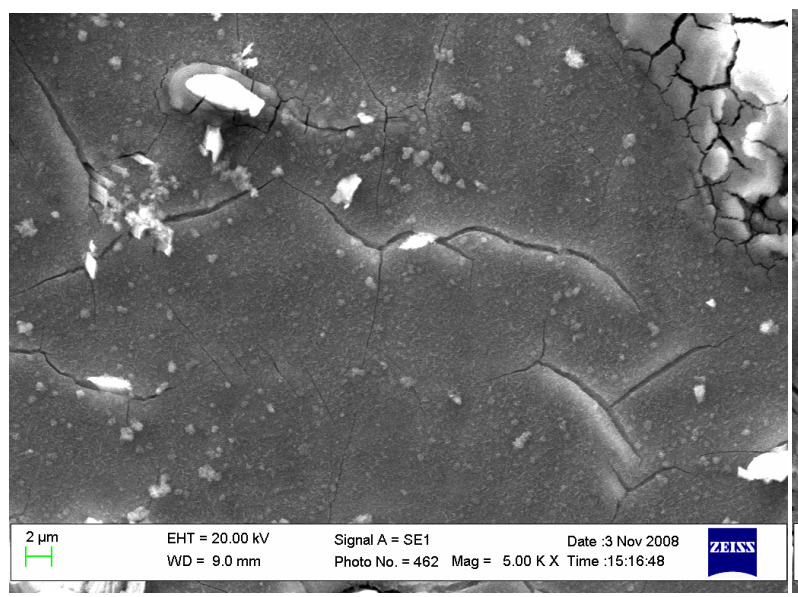

(a)

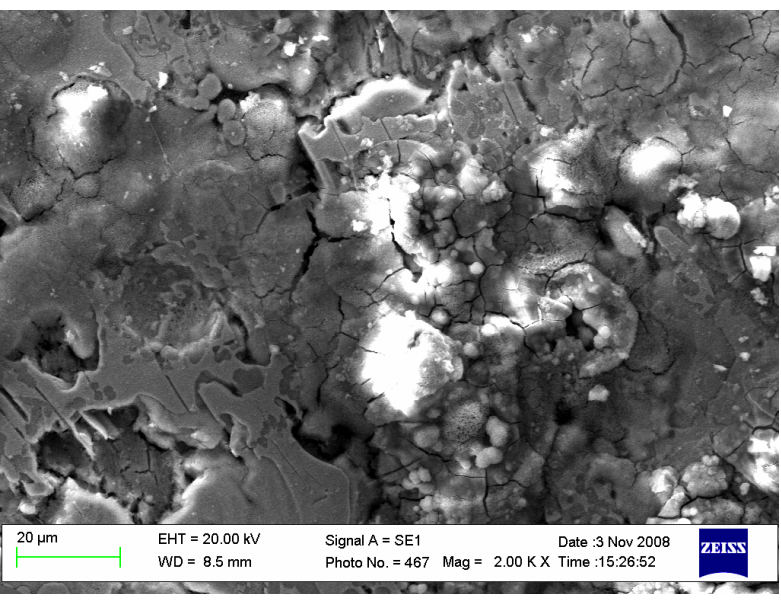

(b)

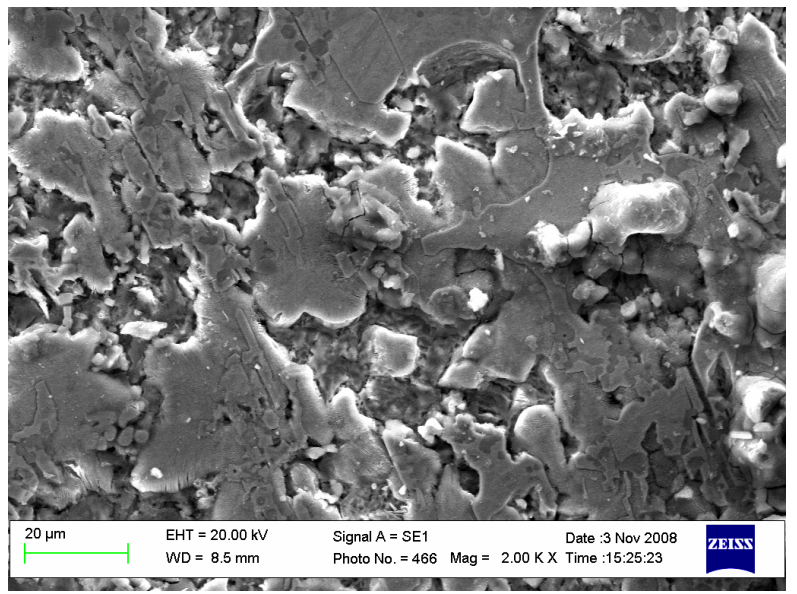

(c)

Figure 4. Corroded SEM micrographs of (a) Hadfield manganese austenitic steel, (b) 5 vol\% and (c) 10 vol\% TiC-reinforced composites. 


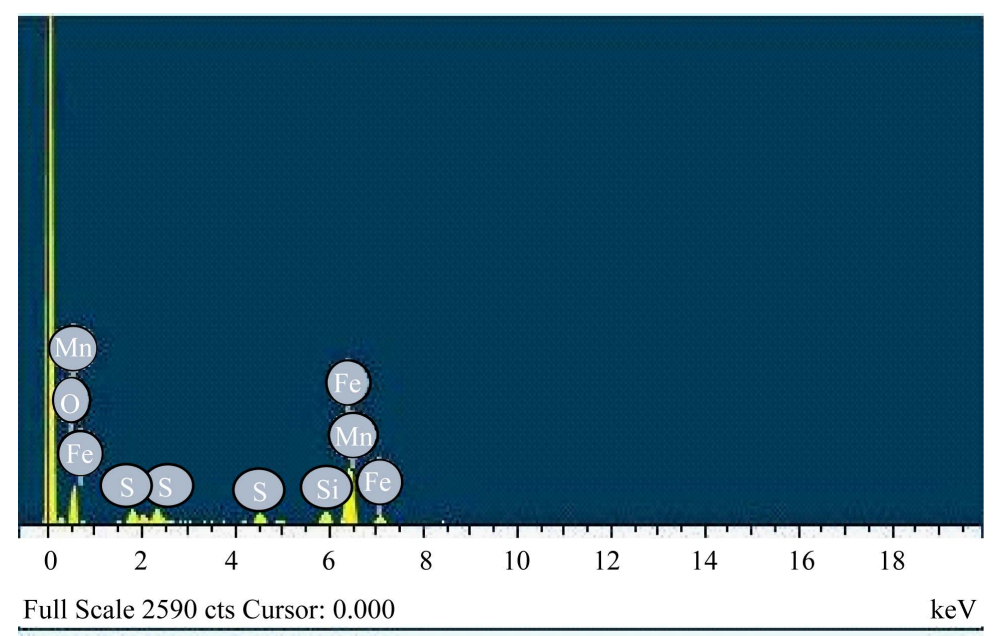

Figure 5. EDX of the corrosion products.

The role of manganese sulphide inclusions on the pitting corrosion resistance has been discussed in the literature [10]-[13]. Manganese sulphide is harmful to the localized corrosion resistance due to its high solubility in chloride acid environments. The dissolution of this type of inclusion creates preferential sites for pit nucleation [14]. Continuous pits are observed at the particle-matrix interface suggesting an appreciable amount of corrosion at the interfacial region.

Figure 4(b) and Figure 4(c) show the corroded SEM micrographs of 5 and 10 vol\% TiC-reinforced composites, respectively. As similar to the unreinforced matrix material, it has been observed that the pitting corrosion is of localized type and the surfaces are covered with the corrosion products. Continuous pits are observed at the particle-matrix interface suggesting an appreciable amount of corrosion at the interfacial region. It has been reported in the literature that in composites, the interfaces are preferred sites for the initiation of pitting [15]-[17]. The severe corrosion in composites can be attributed to the formation of large number of local galvanic cells between austenite and noble $\mathrm{TiC}$ particles or ferrite or $(\mathrm{Fe}, \mathrm{Mn})_{3} \mathrm{C}$ which acts as a cathode during electrochemical corrosion test.

The higher corrosion rate of the composites compared to their unreinforced matrix alloy can be attributed to the additional corrosion taking place at the particle-matrix interfacial region. With the increase of the amount of TiC reinforcing particles, the number of local galvanic cells at the interface increases and thereby increasing the possibility for the formation of more pits. Hence, the composite with $10 \mathrm{vol} \% \mathrm{TiC}$ underwent higher galvanic corrosion compared to that of the composite with 5 vol\% TiC.

\section{Summary}

To summarize, in situ synthesis of 5 and 10 vol\% TiC-reinforced Hadfield austenitic manganese steel matrix composites has been done by conventional melting and casting route. The corrosion rate of the composites is higher than their matrix alloy and it increases with the increase in the volume fraction of the reinforcement.

\section{Acknowledgements}

The authors would like to thank Prof. Koh-ichi Sugimoto, Department of Mechanical Systems Engineering, Faculty of Engineering, Shinshu University, Nagano, Japan for his valuable discussion and suggestion. We would like to thank reviewers and editors for their helpful comments and suggestions in improving this paper.

\section{References}

[1] Rai, V.K., Srivastava, R., Nath, S.K. and Ray, S. (1999) Wear in Cast Titanium Carbide Reinforced Ferrous Composites under Dry Sliding. Wear, 231, 265-271. http://dx.doi.org/10.1016/S0043-1648(99)00127-1

[2] Vallauri, D., Atías Adrián, I.C. and Chrysanthou, A. (2008) TiC-TiB ${ }_{2}$ Composites: A Review of Phase Relationships, Processing and Properties. Journal of the European Ceramic Society, 28, 1697-1713. 
http://dx.doi.org/10.1016/j.jeurceramsoc.2007.11.011

[3] Wang, H.Y., Jiang, Q.C., Ma, B.X., Wang, Y. and Zhao, F. (2005) Reactive Infiltration Synthesis of TiB 2 -TiC Particulates Reinforced Steel Matrix Composites. Journal of Alloys and Compounds, 391, 55-59. http://dx.doi.org/10.1016/j.jallcom.2004.08.045

[4] Wang, Y., Zhang, Q., Wang, Y., Ma, B.X. and Jiang, Q.C. (2006) Effect of Fe Content in Fe-Ti-B System on Fabricating $\mathrm{TiB}_{2}$ Particulate Locally Reinforced Steel Matrix Composites. Materials Science and Engineering, 422, 339-345. http://dx.doi.org/10.1016/j.msea.2006.02.012

[5] Trueman, A., Schweinsberg, D.P. and. Hope, G.A (1997) The Matrix Corrosion of Tungsten Carbide/Carbon Steel Metal Matrix Composites. Corrosion Science, 39, 1153-1164.

http://dx.doi.org/10.1016/S0010-938X(97)00014-0

[6] Lo, K.H., Kwok, C.T., Cheng, F.T. and Man, H.C. (2003) Corrosion Resistance of Laser-Fabricated Metal-Matrix Composite Layer on Stainless Steel 316L. Journal of Laser Applications, 15, 107-114. http://dx.doi.org/10.2351/1.1536649

[7] Pagounis, E. and Lindroos, V.K. (1998) Processing and Properties of Particulate Reinforced Steel Matrix Composites. Materials Science and Engineering, 246, 221-234.

http://dx.doi.org/10.1016/S0921-5093(97)00710-7

[8] Debata, M. and Upadhyaya, G.S. (2001) Corrosion Behavior of Powder Metallurgy $\mathrm{Y}_{2} \mathrm{O}_{3}$ Dispersed Iron-and Nickel-Base Superalloys. Journal of Materials Engineering and Performance, 10, 602-607. http://dx.doi.org/10.1361/105994901770344764

[9] Stearn, M. (1958) The Mechanism of Passivating-Type Inhibitors. Journal of the Electrochemical Society, 105, 638647. http://dx.doi.org/10.1149/1.2428683

[10] Nath, D. and Namboodhirt, T.K.G. (1989) Corrosion Science 29, 1215-1229. http://dx.doi.org/10.1016/0010-938X(89)90068-1

[11] Nunes, P.C.R. and Ramanathan, L.V. (1995) Some Corrosion Characteristics of Aluminium-Mica Particulate Composites. Corrosion, 51, 610-617. http://dx.doi.org/10.5006/1.3293621

[12] Shimizu, Y., Nishimura, T. and Matsushima, I. (1995) Corrosion Resistance of Al-Based Metal Matrix Composites. Materials Science and Engineering, 198, 113-118. http://dx.doi.org/10.1016/0921-5093(95)80065-3

[13] Stewart, J. and Williams, D.E. (1992) The Initiation of Pitting Corrosion on Austenitic Stainless Steel: On the Role and Importance of Sulphide Inclusions. Corrosion Science, 33, 457-463, 465-474. http://dx.doi.org/10.1016/0010-938X(92)90074-D

[14] Baker, M.A. and Castle, J.E. (1992) The Initiation of Pitting Corrosion of Stainless Steels at Oxide Inclusions. Corrosion Science, 33, 1295-1303, 1305-1312. http://dx.doi.org/10.1016/0010-938X(92)90137-R

[15] Nath, D. and Namboodhirt, T.K.G. (1989) Some Corrosion Characteristics of Aluminium-Mica Particulate Composites. Corrosion Science, 29, 1215-1229. http://dx.doi.org/10.1016/0010-938X(89)90068-1

[16] Nunes, P.C.R. and Ramanathan, L.V. (1995) Corrosion Behavior of Alumina-Aluminum and Silicon Carbide-Aluminum Metal-Matrix Composites. Corrosion, 51, 610-617. http://dx.doi.org/10.5006/1.3293621

[17] Shimizu, Y., Nishimura, T. and Matsushima, I. (1995) Corrosion Resistance of Al-Based Metal Matrix Composites. Materials Science and Engineering, 198, 113-118. http://dx.doi.org/10.1016/0921-5093(95)80065-3 